\title{
Restricting time at pasture: Effects on dairy cow herbage intake, foraging behavior, hunger-related hormones, and metabolite concentration during the first grazing session
}

\author{
P. Gregorini, ${ }^{1}$ C. E. F. Clark, J. G. Jago, C. B. Glassey, K. L. M. McLeod, and A. J. Romera \\ DairyNZ, Private Bag 3221, Hamilton, New Zealand
}

\begin{abstract}
This study investigated the effect of restricting grazing time on circulating concentrations of ghrelin, nonesterified fatty acids (NEFA), and glucose before, and foraging behavior of dairy cows during, the first grazing session of the day (GS, 0800-1200 h). Fortyeight Holstein-Friesian cows ( $470 \pm 47 \mathrm{~kg}$ of BW; $35 \pm$ $9 \mathrm{~d}$ in milk) were strip-grazed on a perennial ryegrass pasture for either $4 \mathrm{~h}$ after each milking $(2 \times 4), 8 \mathrm{~h}$ between milkings $(1 \times 8)$, or the 24 -h period excluding milking times (CTL). Cows were bled before the GS; plasma was analyzed for ghrelin and serum for glucose and NEFA. Herbage mass was measured pregrazing $(0730 \mathrm{~h})$, during and at the end of the GS (1200 h), and postgrazing ( $24 \mathrm{~h}$ after the first measurement). Herbage mass data were fitted to a model to estimate herbage disappearance rates. Herbage intake and bite mass were calculated using herbage mass disappearance and behavioral measurements. Bite rate, eating, searching, ruminating, and idling time were determined during the GS for each cow. No difference in glucose concentration was found between treatments. Concentrations of NEFA and ghrelin were the greatest for cows in the $1 \times 8$ treatment. Daily herbage intake did not differ between treatments; however, during the GS $1 \times$ 8 had a greater herbage intake than $2 \times 4$ and CTL. Bite mass differed between treatments and throughout the GS. Bite mass was smallest for CTL during the first $60 \mathrm{~min}$ and greatest during the last $90 \mathrm{~min}$, when cows in the $2 \times 4$ treatment had the smallest bite mass. Cows in $1 \times 8$ spent the longest time eating and the least time searching and ruminating. Eating time was greatest for $1 \times 8$ during the first 60 and last $90 \mathrm{~min}$ of the GS. Searching time only differed in the second 60 min, when it was the lowest for $1 \times 8$. Cows from all treatments did not ruminate during the first $120 \mathrm{~min}$. Cows in CTL had the greatest rumination time during the last $90 \mathrm{~min}$. The model fitted to represent dynamics
\end{abstract}

Received April 23, 2009.

Accepted June 2, 2009.

${ }^{1}$ Corresponding author: Pablo.Gregorini@dairynz.co.nz of herbage mass disappearance presented differences in the fractional herbage disappearance rate. There was an interaction between treatment and time in herbage depletion rate. The results of this study present a fuller picture of foraging dynamics during the first $4 \mathrm{~h}$ of grazing and its potential relationship with physiological markers of hunger as affected by grazing management. Key words: dairy cow, available grazing time, foraging behavior, hunger-regulated hormones and metabolites

\section{INTRODUCTION}

The grazing process has been described as a series of interactions between ingestive and digestive processes (Allden and Whittaker, 1970) and hormonal and metabolic stimuli to herbage intake (Illius and Jessop, 1996; Roche et al., 2008a). However, most of the advances in the understanding of the plant-animal interface have come from research determining how sward structure influences the instantaneous rate of herbage intake (Laca et al., 2001). Although recent integrative research (Gregorini et al., 2009) has focused on the interaction between plant, rumen, and endocrine-metabolic factors influencing grazing behavior, until now few related field studies have been undertaken.

Hunger motivates animals to eat. The key stimuli determining the degree of such a motivation are time available to eat and time elapsed from the last meal (i.e., deprivation; Jensen and Toates, 1993; Staddon, 2003). Hunger level motivates particular behavioral actions, determining foraging tactics and strategies (Pittroff and Soca, 2006). As deprivation increases, instantaneous intake rate increases by increments of grazing time, bite mass, and bite rate (Patterson et al., 1998; Chilibroste et al., 2007). Consistent with these increments, Gregorini et al. (2007a) and Gregorini et al. (2009) reported dynamic changes in foraging tactics and strategies by beef heifers and dairy cows, respectively, as hunger level (represented by rumen fill) increased. These changes appear to be mediated by energy status of the animal and hormonal stimuli such as the orexigenic agent ghrelin (Gregorini et al., 2009). Changes in ingestive behavior relate to satiety factors 
and feeding behavior stimuli/motivation at a discrete meal level (Ivlev, 1961). This is extensively studied in humans, rats, and swine (Day and Rogers, 1997; Day et al., 1998), but little research has been carried out in grazing dairy cows.

In a context of strip-grazing management, cattle consume the bulk of the day's allocated herbage during the first hours of grazing. Consequently, foraging strategies during this period are key determinants of daily herbage intake (Galli and Cangiano, 1999; Soca et al., 2002a; Soca, 2006). Recent research (Kennedy et al., 2009; Perez-Ramirez et al., 2009) investigated the effects of timing and availability of time for grazing (1 vs. 2 periods of available time for grazing, and restricted vs. nonrestricted time to graze, respectively) on milk production and daily herbage intake. However, there is a lack of detailed information about how cows adapt to different herbage allocations and restrictions. The objective of the present study was to investigate and describe the foraging behavior of dairy cows during the first grazing session of the day (GS, 0800-1200 h) in response to restrictions in available grazing time, and its association with changes in circulating concentrations of hunger-related hormones and metabolites.

\section{MATERIALS AND METHODS}

This study was approved by the Committee of Animal Care and Use from AgResearch (Hamilton, New Zealand).

\section{Site, Animals, and Treatments}

The study was conducted at Scott Farm, DairyNZ (Hamilton, New Zealand) during September and October 2008. Forty-eight Holstein-Friesian cows (470 \pm 47 $\mathrm{kg}$ of BW; $35 \pm 9$ DIM; $24.2 \pm 0.2 \mathrm{~kg} / \mathrm{d} ; 4.5 \pm 0.15 \%$ fat; $3.5 \pm 0.06 \%$ protein) were randomly assigned to 6 groups $(\mathrm{n}=8 /$ group $)$ and grazed according to the following treatments (2 groups per treatment): either $4 \mathrm{~h}$ after each milking $(2 \times 4), 8 \mathrm{~h}$ between milkings $(1 \times$ 8), or the 24-h period excluding milking times (CTL). Adaptation to dietary regimen is important in this case of studies. Animals need to strategize their foraging behavior according to their accessibility to pasture. Therefore, although cows in all treatments grazed the same sward, cows were adapted to treatments for a period of $16 \mathrm{~d}$. Measurements took place during the last $3 \mathrm{wk}(1 \mathrm{~d} / \mathrm{wk})$ of the experimental period.

\section{Pasture and Grazing Management}

During the treatment adaptation and experimental period, cows were strip-grazed on a perennial ryegrass dominated pasture (Lolium perenne L., 79.4\%; Trifolium repens, 3.3\%; Poa annua and trivialis, 7.3\%; and broadleaf weeds, $10 \%)$. Chemical composition of herbage was CP, 20.3\%; ADF, 22.5\%; NDF, $41.9 \%$; NSC, $12.9 \%$, and lipids, $3.7 \%$. Herbage allowance was $0.07 \mathrm{~kg}$ of herbage $\mathrm{DM} / \mathrm{kg}$ of $\mathrm{BW}$ per day for all treatments. Mean pregrazing herbage mass for the experimental period was $3,191 \mathrm{~kg}$ of $\mathrm{DM} / \mathrm{ha}$. The new daily strip of pasture (herbage) was allocated at $0800 \mathrm{~h}$ (after morning milking). Cows in treatments $1 \times 8$ and $2 \times 4$ were restricted to access pasture (taken off from pasture) in a wood chip-covered pad according to the timing, and available grazing time, of each treatment. All cows were milked at 0700 and $1600 \mathrm{~h}$. Cows did not receive feed or mineral supplements and had ad libitum access to fresh water in each daily strip of pasture and on the "stand-off" pad.

\section{Measurements and Calculations}

Blood Collection and Ghrelin, NEFA, and Glucose Analysis. Each cow was blood sampled between 0600 and $0700 \mathrm{~h}$ before the GS (0800-1200 h). Samples were collected by coccygeal venipuncture into $10-\mathrm{mL}$ evacuated blood tubes (140 IU of sodium heparin and $0.117 \mathrm{~mL}$ of $\left.15 \% \mathrm{~K}_{3} \mathrm{EDTA}\right)$. Samples were placed on ice until centrifuged $(1,500 \times g, 15 \mathrm{~min}$, $4^{\circ} \mathrm{C}$ ). Plasma from the $\mathrm{K}_{3}$ EDTA tubes was acidified using $1 \mathrm{~N} \mathrm{HCl}$ and treated with a protease inhibitor (10 $\mu \mathrm{L}$ of phenylmethylsulfonyl fluoride) before storage for further analysis. Plasma active (acetylated) ghrelin concentrations were determined using a commercially available RIA (multispecies ghrelin active kit/GHRA88HK, Linco Research Inc., St. Charles, MO). This assay uses ${ }^{125}$ I-labeled ghrelin and a ghrelin antiserum to determine plasma concentration of ghrelin by the double antibody-polyethylene glycol technique and was validated for cows by Roche et al. (2008b). The lowest level of ghrelin that can be detected by this assay is 7.8 $\mathrm{pg} / \mathrm{mL}$ when using a $100-\mu \mathrm{L}$ sample size. Intraassay coefficient of variation (CV) was $<10 \%$. Analyses for NEFA (colorimetric method) and glucose (hexakinase method) were performed on a Hitachi 717 analyzer (Roche, Basel, Switzerland) at $30^{\circ} \mathrm{C}$ by Alpha Scientific Ltd. (Hamilton, New Zealand). The inter- and intraassay CV were $<2 \%$ for NEFA and glucose.

Foraging Behavior. Behavioral activities were determined during the GS. Six trained observers were randomly assigned to each group of cows to record eating, searching, rumination, and idling behavior every 2 min by scan-sampling as suggested by Hirata et al. (2002). From these data, times for each activity were calculated by multiplying each behavior activity frequency by a 2-min interval; when grazing, cattle search, 
acquire into the mouth, masticate, and swallow herbage (Gibb, 1998). For the purpose of this experiment, eating behavior was defined as cows with heads down and engaged in acquiring herbage into the mouth. Walking head down without eating was considered a searching activity. Observers counted bites of each cow during one continuous minute at $0,30,60$, and $120 \mathrm{~min}$ after the GS started. Times spent eating, searching, ruminating, and idling, along with bite rate and herbage intake, were summarized into means for the GS. Eating, searching, ruminating, and idling times were also summarized into 3 periods within the GS: 0-60, 60-120, and 120-210 min.

Herbage Intake, Bite Mass, and Pasture Disappearance Rate. These variables were estimated using data from herbage mass measurements. Herbage mass was measured using a rising plate meter fitted with an electronic counter (Farmworks, Palmerston North, New Zealand). Herbage mass was recorded pregrazing, during (at 30, 60 and 120 min after GS started) the GS, at the end of the GS, and postgrazing (end of $24 \mathrm{~h}$ ). Each recording was based on 0.075 plate meter readings per square meter of the area (strip) being grazed at the time. Plate meter readings followed the same transect path in all recordings. Pasture strips were always rectangular with an average area of $800 \mathrm{~m}^{2}$.

Daily herbage intake was estimated by difference between pre- and postgrazing herbage mass (Macoon et al., 2003; McEvoy et al., 2007). Herbage intake for the GS was calculated as the difference between pregrazing herbage mass and herbage mass at the end of the GS. The mean bite mass for GS was calculated by dividing herbage intake from the GS by the calculated total number of bites taken per cow during the GS. The latter was calculated by multiplying bite rate and eating time. Bite mass for the 3 periods within the GS were calculated in a similar way to the GS herbage intake. In this case, herbage intake per period was divided by the number of bites per cow at each period.

Herbage mass disappearance rate was calculated by fitting herbage mass data $(y)$ taken from each group of cows to the model of Ørskov and McDonald (1970) $\{y=a-b[1-\exp (-c \times$ time $)]\}$. For the present study, $a$ represented initial available herbage mass; $b$, potential herbage mass disappearance; and $c$, fractional disappearance rate $(\% / \mathrm{h})$ of herbage mass. Parameters were estimated using GenStat 11.1 (Payne et al., 2008). Instantaneous herbage mass disappearance rates $(\mathrm{kg}$ of herbage DM/ha per hour) were estimated for 0, 60, 120, and $210 \mathrm{~min}$ after the GS started as the first derivative of the function $y^{\prime}=-b \times c \times \exp (-c \times$ time $)$.

\section{Statistical Analysis}

Data from individual cows were averaged to obtain 6 experimental unit values per day of sampling, which were then analyzed as follows. Treatment effect on circulating concentration of ghrelin, NEFA, and glucose, and mean eating, searching, ruminating, and idling time, bite rate, bite mass, herbage intake during the GS, and daily herbage intake were analyzed using ANOVA, including group of cow as a random effect. Group of cows was the experimental unit. Repeated measurements through the GS were analyzed by mixed models, with treatment, time, and interaction of treatment with time as fixed effects, and cow group as a random effect. A compound symmetry covariance structure was used for within-group repeated measurements, and heterogeneity of variance at the time points was allowed for. Significant interactions between time and treatment were investigated further using ANOVA at each time point. Pasture depletion was analyzed by fitting the model of Ørskov and McDonald (1970) to the data from each group, and then analyzing the parameter estimates and herbage mass disappearance rates at the different time points using ANOVA with cow group as the experimental unit. GenStat 11.1 was used for all statistical analysis (Payne et al., 2008).

\section{RESULTS}

\section{Herbage Intake and Grazing Behavior}

Herbage intake during the GS was greater $(P<0.05)$ for cows in $1 \times 8$ than for cows in $2 \times 4$ or CTL, whereas daily herbage intake did not differ $(P<0.05)$ between treatments (Table 1). During the GS, cows in 1 $\times 8$ had greatest $(P<0.05)$ mean eating time, cows in CTL had the lowest, and $2 \times 4$ cows were intermediate (Table 1). Mean searching time was lower $(P<0.05)$ for cows in $1 \times 8$ than for cows in $2 \times 4$ and CTL, which did not differ from each other (Table 1). Cows in CTL had the greatest mean rumination time, with cows in 1 $\times 8$ and $2 \times 4$ not different from each other $(P<0.05)$. Mean idling time did not differ among treatments $(P>$ $0.05)$. Mean bite rate was least $(P<0.05)$ for cows in CTL and greatest $(P<0.05)$ for cows in $2 \times 4$ (Table $1)$. Mean bite mass was greater $(P<0.05)$ for cows in CTL than cows in $2 \times 4$.

Eating time during the first $60 \mathrm{~min}$ of the GS was greatest $(P<0.05)$ for cows in $1 \times 8$ (Table 2$)$. During the second $60 \mathrm{~min}$ of the GS, treatment did not affect $(P>0.05)$ eating time. During the last $90 \mathrm{~min}$ of the GS cows in $1 \times 8$ spent more $(P<0.05)$ time eating 
Table 1. Effects of allocation of available grazing time on herbage intake; eating, searching, ruminating, and idling times ${ }^{1}$ and bite rate and mass during the first grazing session (GS) of Holstein-Friesian dairy cows grazing a perennial ryegrass pasture

\begin{tabular}{|c|c|c|c|c|c|}
\hline \multirow[b]{2}{*}{ Item } & \multicolumn{3}{|c|}{ Treatment $^{2}$} & \multirow[b]{2}{*}{$\mathrm{SED}^{3}$} & \multirow{2}{*}{$\begin{array}{c}\text { Treatment } \\
\text { effect } \\
(P \text {-value })\end{array}$} \\
\hline & $1 \times 8$ & $2 \times 4$ & CTL & & \\
\hline Herbage intake during GS, $\mathrm{kg}$ of DM/cow & $11.5^{\mathrm{a}}$ & $9.2^{\mathrm{b}}$ & $9.4^{\mathrm{b}}$ & 0.340 & 0.012 \\
\hline Daily herbage intake, $\mathrm{kg}$ of $\mathrm{DM} / \mathrm{cow}$ & 12.5 & 13.9 & 13.7 & 1.233 & 0.528 \\
\hline Eating & $0.81^{\mathrm{a}}$ & $0.68^{\mathrm{b}}$ & $0.58^{\mathrm{c}}$ & 0.021 & 0.004 \\
\hline Searching & $0.02^{\mathrm{b}}$ & $0.05^{\mathrm{a}}$ & $0.07^{\mathrm{a}}$ & 0.008 & 0.018 \\
\hline Ruminating & $0.009^{\mathrm{b}}$ & $0.012^{\mathrm{b}}$ & $0.112^{\mathrm{a}}$ & 0.032 & 0.079 \\
\hline Idling & 0.13 & 0.21 & 0.21 & 0.027 & 0.119 \\
\hline Bite rate, bites $/ \mathrm{min}$ & $52.1^{\mathrm{b}}$ & $54.9^{\mathrm{a}}$ & $46.47^{\mathrm{c}}$ & 0.541 & 0.001 \\
\hline Bite mass, $\mathrm{g}$ of $\mathrm{DM}$ & $1.28^{\mathrm{ab}}$ & $1.10^{\mathrm{bc}}$ & $1.46^{\mathrm{a}}$ & 0.064 & 0.026 \\
\hline
\end{tabular}

than cows in $2 \times 4$ or CTL. Searching time during the first 60 min of the GS did not differ between treatments $(P>0.05 ;$ Table 2$)$. Treatment affected $(P>0.05)$ the time cows spent searching during the second $60 \mathrm{~min}$ of the GS, with cows in $2 \times 4$ and CTL searching for longer than cows in $1 \times 8(P<0.05)$. During the last 90 min of the GS, treatment did not affect searching time $(P>0.05)$. Cows did not ruminate during the first 120 min of the GS, and CTL cows ruminated longer $(P$ $<0.05)$ than cows in either $1 \times 8$ or $2 \times 4$ during the last 90 of the GS (Table 2). Idling time only differed for the first $60 \mathrm{~min}$ of the GS; cows in $1 \times 8$ and $2 \times$ 4 spent less time idling then CTL cows $(P<0.05)$. Bite mass also differed at the beginning and the end of the GS (Table 2). During the first $60 \mathrm{~min}$, cows in $1 \times 8$ and $2 \times 4$ had a greater bite mass than cows in CTL $(P<0.05)$. In comparison, cows in CTL had the greatest bite mass and cows in $2 \times 4$ had the smallest bite mass during the last $90 \mathrm{~min}$ of the GS $(P<0.05)$. Cows in $2 \times 4$ started $(\min 0)$ at a greater $(P<0.05)$ bite rate than cows in $1 \times 8$ and CTL. At $30 \mathrm{~min}$, cows in $2 \times 4$ had the greatest bite rate and cows in CTL the lowest $(P<0.05)$, with cow $1 \times 8$ cows having an intermediate rate. At $60 \mathrm{~min}$, cows in $1 \times 8$ and $2 \times 4$ had greater $(P<0.05)$ bite rate than cows in CTL. At $120 \mathrm{~min}$, cows in $2 \times 4$ had the greatest bite rate, cows in CTL had the least, and $1 \times 8$ cows were intermediate $(P<0.05)$.

\section{Pasture Disappearance}

The treatment effect on pasture disappearance dynamics is presented in Figure 1. Table 3 provides the parameter estimates for the model used to represent herbage mass disappearance rate and rates at differ- ent time points of the GS. Fractional disappearance of herbage (parameter $c)$ differed $(P<0.05)$ between treatments, whereas parameters $a$ and $b \operatorname{did}$ not $(P>$ $0.05)$. Herbage disappearance rate differed $(P<0.05)$ between treatments at times 0,60 , and $120 \mathrm{~min}$. At time $0,1 \times 8$ and $2 \times 4$ showed greater $(P<0.05)$ herbage disappearance rate than CTL. At 60 min, $1 \times$ 8 had greater $(P<0.05)$ disappearance rate than $2 \times 4$ and CTL. At 120 and $210 \mathrm{~min}, 1 \times 8$ and CTL showed greater disappearance rate than $2 \times 4$.

\section{Ghrelin, NEFA, and Glucose Concentrations}

Cows in $1 \times 8$ had the greatest ghrelin concentration $(P<0.05)$ at $0700 \mathrm{~h}$, whereas ghrelin concentration did not differ between cows in $2 \times 4$ and CTL (Table $4)$. Cows in $1 \times 8$ also had greater $(P<0.05)$ NEFA concentrations than cows in $2 \times 4$, but were not different $(P>0.05)$ from cows in CTL. Plasma glucose was not affected by treatment $(P>0.05)$.

\section{DISCUSSION}

\section{Daily Herbage Intake}

Cows integrate internal stimuli (i.e., products of digestion) and external incentives (i.e., grazing management/opportunities to eat) to regulate herbage intake, which may explain how and why cattle change shortterm foraging tactics and strategies (Houston, 1993; Soca et al., 2002a,b) to maintain a target daily food intake.

In the present study, daily herbage intake was not affected by timing or availability of time to graze. The lack of effect of the timing of pasture restriction confirm 
the reports of Kennedy et al. (2009) and Perez-Ramirez et al. (2009), who did not report an effect of timing of available grazing time $(1 \times 9$ vs. $2 \times 4.5$ and $1 \times 9$ vs. $2 \times 2.75$, respectively) on daily herbage intake of dairy cows. However, these studies reported a reduction of daily herbage intake for cows restricted in available grazing time when compared with the daily herbage intake of unrestricted cows. Conversely, Mattiauda et al. (2004), Chilibroste et al. (2004a), and Kristensen et al. (2007) reported no reduction in daily herbage intake of dairy cows when available grazing time was reduced from 22 to 16,8 , and $4 \mathrm{~h} / \mathrm{d}$, as did Gregorini et al., (2007b) and Gregorini et al. (2008) with beef heifers. Chilibroste et al. (2004a) and Mattiauda et al. (2004) evaluated the effect of available grazing time and herbage allowance on daily herbage intake. According to these studies, unrestricted levels of herbage allowance overcome reductions in available grazing time. Poppi et al. (1987) set a threshold of herbage allowance of $0.04 \mathrm{~kg}$ of $\mathrm{DM} / \mathrm{kg}$ of $\mathrm{BW}$ per day below which herbage intake would be constrained. The level of herbage allowance in the present study and that of Kennedy et al. (2009) were similar and both levels were greater than the threshold suggested by Poppi et al. (1987). It appears that the lack of difference between restricted and nonrestricted cows in the present experiment may have been related to differences, compared with Kennedy et

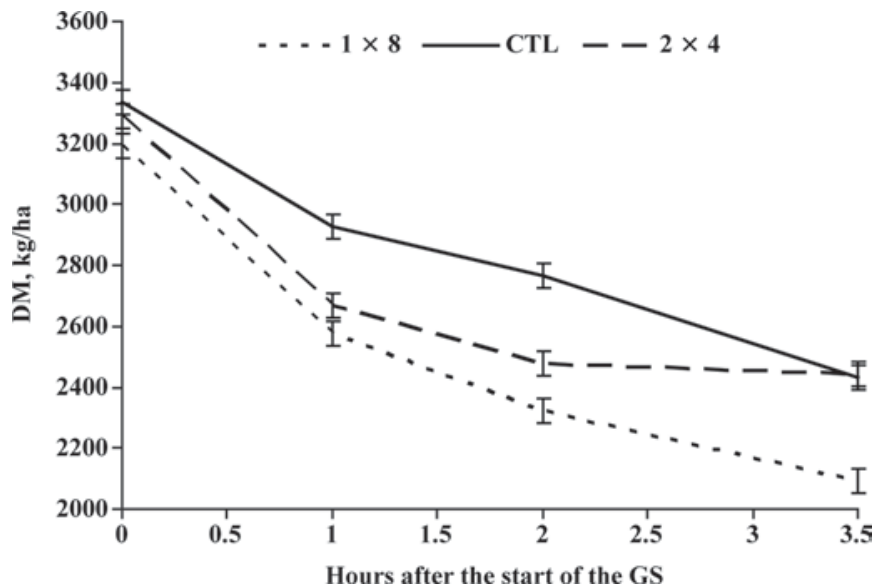

Figure 1. Herbage mass disappearance during the first grazing session (GS) of the day for Holstein-Friesian dairy cows grazing a perennial ryegrass pasture with differences in allocation of available grazing time. $1 \times 8=8 \mathrm{~h}$ of available grazing time allocated between morning and afternoon milkings; $2 \times 4=8 \mathrm{~h}$ of available grazing time allocated in 2 sets of $4 \mathrm{~h}$ after morning and afternoon milking; CTL (control) $=24$-h period excluding milking times. Cows spent $4 \mathrm{~h} / \mathrm{d}$ in the milking process.

al. (2009), in hunger drive and herbage accessibility, as well as the interaction between these two factors. Because cows in the present study were in the first stage of lactation, a greater motivation to eat can be expected. In addition, they were not fed supplements.

Table 2. Effects of allocation of available grazing time on the dynamics of eating, searching, ruminating, and idling times, bite mass, and bite rate during the first grazing session of the day for Holstein-Friesian dairy cows grazing a perennial ryegrass pasture

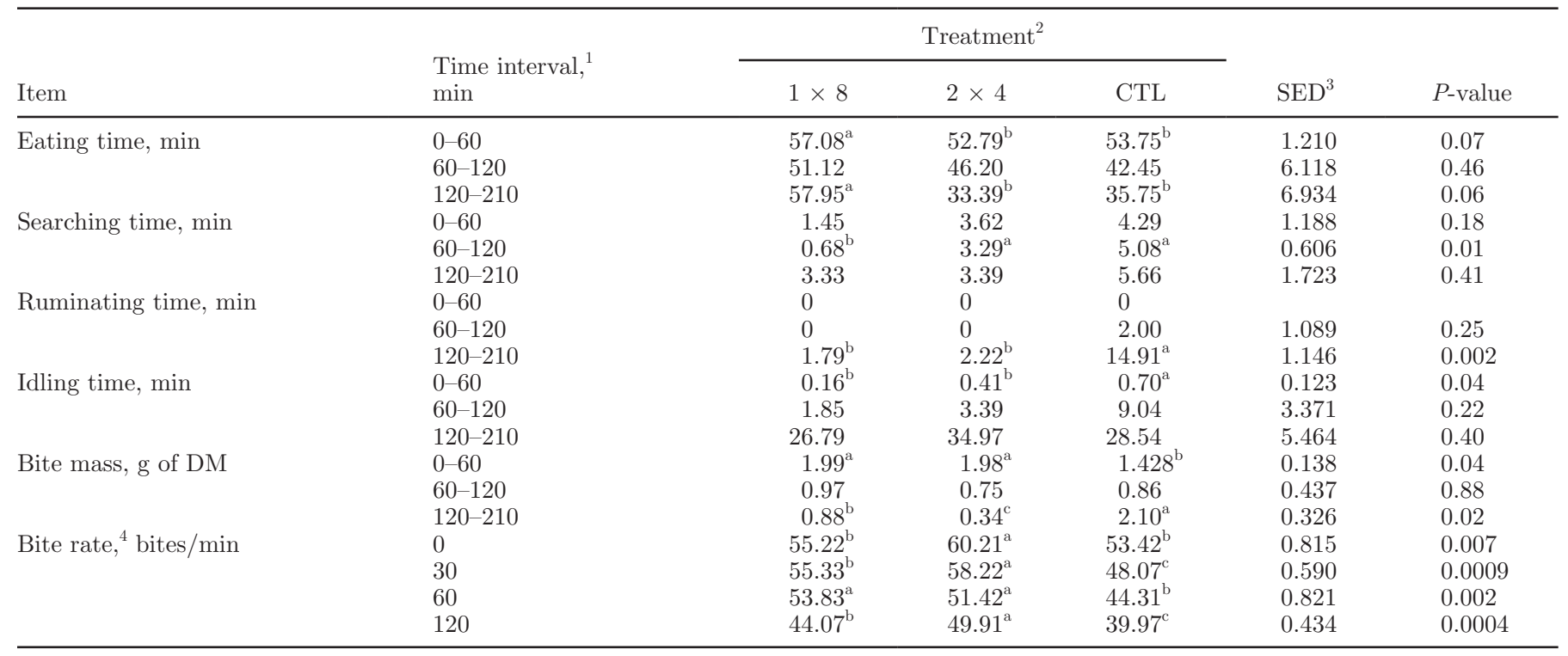

${ }^{\mathrm{a}-\mathrm{c}}$ Means in the same row with different superscripts are different $(P<0.05)$.

${ }^{1}$ Interval of time during the first meal, 0 min (start) and 210 min (end).

${ }^{2} 1 \times 8=8 \mathrm{~h}$ of available grazing time allocated between morning and afternoon milkings; $2 \times 4=8 \mathrm{~h}$ of available grazing time allocated in 2 sets of $4 \mathrm{~h}$ after morning and afternoon milking; CTL (control) $=24$-h period excluding milking times. Cows spent $4 \mathrm{~h} / \mathrm{d}$ in the milking process.

${ }^{3}$ Standard error of difference.

${ }^{4}$ Fixed point in time (min after meal started). 
Table 3. Effects of allocation of available grazing time on herbage disappearance dynamics (calculated parameters and rates of disappearance at different times) during the first grazing session of the day for Holstein-Friesian dairy cows grazing a perennial ryegrass pasture ${ }^{1}$

\begin{tabular}{|c|c|c|c|c|c|}
\hline Item & \multicolumn{3}{|c|}{ Treatment $^{2}$} & $\mathrm{SED}^{3}$ & $\begin{array}{c}\text { Treatment } \\
\text { effect }(P \text {-value })\end{array}$ \\
\hline$b$ & $1,206.5$ & 865.1 & $1,649.8$ & 387.4 & 0.262 \\
\hline$c$ & $0.689^{\mathrm{b}}$ & $1.314^{\mathrm{a}}$ & $0.277^{\mathrm{c}}$ & 0.158 & 0.016 \\
\hline \multicolumn{6}{|c|}{ Herbage disappearance rate, $\mathrm{kg}$ of $\mathrm{DM} /$ ha per hour } \\
\hline At time $0(0 \mathrm{~min})$ & $821.6^{\mathrm{a}}$ & $1,137.9^{\mathrm{a}}$ & $397.2^{\mathrm{b}}$ & 125.2 & 0.022 \\
\hline At time $3.5(210 \mathrm{~min})$ & $76.7^{\mathrm{a}}$ & $11.7^{\mathrm{b}}$ & $150.1^{\mathrm{a}}$ & 33.0 & 0.056 \\
\hline
\end{tabular}

${ }^{\mathrm{a}-\mathrm{c}}$ Means in the same row with different superscripts are different $(P<0.05)$.

${ }^{1}$ Herbage mass taken at different times during the meal was fitted to the model of Ørskov and McDonald $(1970)\{y=a+b[1-\exp (c \times$ time $)]\}$, where $a=$ available herbage (at time 0$) ; b=$ potential herbage disappearance; $c=$ fractional disappearance rate $(\% / \mathrm{h})$.

${ }^{2} 1 \times 8=8 \mathrm{~h}$ of available grazing time allocated between morning and afternoon milkings; $2 \times 4=8 \mathrm{~h}$ of available grazing time allocated in 2 sets of $4 \mathrm{~h}$ after morning and afternoon milking; CTL (control) $=24$-h period excluding milking times. Cows spent $4 \mathrm{~h} / \mathrm{d}$ in the milking process.

${ }^{3}$ Standard error of difference.

Based on area allocation and pregrazing herbage mass, the pasture grazed by the cows in the present study experiment was taller, which may have facilitated herbage ingestion by increasing herbage accessibility (Rook et al., 1994). The interaction of these two factors may partially explain why the restricted cows in the present study have similar intakes to the CTL cows. This argument is also supported by Iason et al. (1999) and Soca et al. (2002b) in sheep and beef cattle, respectively, who reported a positive interaction between length of available grazing time restriction and herbage accessibility on daily herbage intake as determined by sward surface height.

\section{Herbage Intake and Foraging Behavior During the First GS}

Although herbage intake differed between treatments during the GS, cows in all treatments consumed the bulk of their daily herbage intake during the GS (Table 1). This reinforces the importance of the first meal after a natural (i.e., night) or management-generated (i.e., pasture standing-offs) food deprivation on daily herbage intake and, therefore, the foraging strategies used during this period.

Deprivation is defined as the number of hours since the last meal, and its magnitude is positively related to hunger level (Forbes, 1995). The major mechanism by which cattle respond to restrictions in grazing time is to increase eating time during the next available time for grazing (Chilibroste et al., 2004b). In the present study, eating time during the GS was clearly affected by the restriction of total available grazing time and the magnitude of deprivation (Tables 1 and 2). The latter had the strongest effect as motivational stimulus to eat. The way cows allocated eating time during the GS (Table 2) provided evidence that eating motivation for cows in $1 \times 8$ lasted longer than that for cows in $2 \times$ 4 or CTL. This greater eating motivation for cows in 1 $\times 8$ is also observable and supported by the lower idling time during the first 60 min of the GS. These results and the difference in searching time (Tables 1 and 2) are consistent with the incremental increase in eating time and reductions in searching time, with increas-

Table 4. Effects of allocation of available grazing time on circulating ghrelin, NEFA, and glucose at the start of the first grazing session of the day for Holstein-Friesian dairy cows grazing a perennial ryegrass pasture

\begin{tabular}{|c|c|c|c|c|c|}
\hline \multirow[b]{2}{*}{ Item } & \multicolumn{3}{|c|}{ Treatment $^{1}$} & \multirow[b]{2}{*}{$\mathrm{SED}^{2}$} & \multirow{2}{*}{$\begin{array}{l}\text { Treatment effect } \\
\quad(P \text {-value })\end{array}$} \\
\hline & $1 \times 8$ & $2 \times 4$ & CTL & & \\
\hline Ghrelin, mmol/L & $230.4^{\mathrm{a}}$ & $152.6^{\mathrm{b}}$ & $178.8^{\mathrm{b}}$ & 10.05 & 0.009 \\
\hline $\mathrm{NEFA}, \mathrm{mmol} / \mathrm{L}$ & $0.42^{\mathrm{a}}$ & $0.19^{\mathrm{b}}$ & $0.27^{\mathrm{ab}}$ & 0.071 & 0.10 \\
\hline Glucose, $\mathrm{mmol} / \mathrm{L}$ & 3.89 & 3.85 & 3.82 & 0.051 & 0.51 \\
\hline
\end{tabular}


ing hunger levels reported in beef heifers (Gregorini et al., 2007a). This response is reinforced by the results of Wertz-Lutz et al. (2006), who reported increased eating time associated with greater ghrelin concentrations when beef steers were nutritionally restricted. Incremental increases in eating time are often at the expense of ruminating time (Abrahamse et al., 2008). The pattern of both eating and rumination time during the GS support this concept, as well as the view of rumination as an active rather than a passive digestive process. In other words, cattle may decide when to ruminate according to foraging strategy, integrating not only nutritional or internal stimuli but also learned eating expectations (Soca et al., 2002a).

Unexpectedly, CTL cows had a greater average bite mass (Table 1), which could have been related to a high bite mass estimated for the end of the GS (Table 2). Bite mass decreased from the beginning to the end of the GS for both $1 \times 8$ and $2 \times 4$ cows. However, the degree of this reduction was smaller for cows in $1 \times 8$ than in $2 \times 4$. Bite mass is a key variable determining short-term herbage intake rate (Hodgson 1985; Newman et al., 1994) as well as a compensatory foraging tactic in response to food deprivations. Chilibroste et al. (1997) observed a linear decrease in bite mass through a grazing bout as well as a negative effect of artificially filling the rumen. Gregorini et al. (2007a) and Gregorini et al. (2009) reported increases in bite mass by beef heifers and dairy cows, respectively, as hunger level increased. Similarly, Patterson et al. (1998) found that the effect of deprivation on bite mass by dairy cows was greater as the length of deprivation increased. These studies and the bite mass differences throughout the GS between cows in $1 \times 8$ and $2 \times 4$ treatments not only point out the importance of bite mass as a compensatory mechanism for reductions in available grazing time, but also as the immediate response to changes in hunger level. The smaller rate of decline in bite mass from cows in 1 $\times 8$ compared with $2 \times 4$ corroborates the magnitude and persistency of the motivational stimulus to keep eating.

Bite rate differed between treatments and appeared to decrease during the GS (Table 2). Deprivation has been reported to increase bite rate (Dougherty et al., 1989; Patterson et al., 1998; Gregorini et al., 2007b). This was evident in the present study, with CTL cows having lower bite rates than $1 \times 8$ and $2 \times 4$ cows. However, there was not a clear effect of deprivation (time since the last meal) on bite rate when comparing $1 \times 8$ and $2 \times 4$. In fact, bite rate was greatest for $2 \times$ 4 cows for most of the GS. This difference and the fact that cows in $1 \times 8$ had a greater herbage intake during the GS diminish the importance of bite rate as a compensatory mechanism and emphasize the importance of bite mass and eating time in modulating intake rate. These results are supported by the findings of Kennedy et al. (2009), who reported no effect of restricting access time to pasture on mean grazing bites per min and the previous works of Gregorini et al. (2007a) and Gregorini et al. (2009), where beef heifers and dairy cows utilized eating time and bite dimensions, instead of bite rate, as compensatory mechanisms to increase intake rate.

The dynamics of herbage disappearance (Table 3 and Figure 1) can be interpreted and cautiously used as an estimate of herbage intake rate dynamics during the GS. At the beginning of the GS (time 0), restricted cows started consuming herbage at a rate twice as fast as CTL cows. This difference may be supported by variations in bite mass, bite rate, and eating time at the beginning of the GS. Despite the likely lower hunger level of cows in $2 \times 4$ compared with the $1 \times 8$ cows at the start of the GS, they were not different in herbage disappearance rate. The lower ghrelin and NEFA concentrations in $2 \times 4$ cows (Table 4) may indicate that temporal perception (learned expectations) rather than a hunger-related hormone-metabolic signal plays an important role in driving greater herbage intake rates at the beginning of a GS, when a new pasture is allocated. By time 1 ( $1 \mathrm{~h}$ after GS started) the herbage disappearance rate decreased for all treatments, which also matches changes occurring in bite mass, bite rate, and eating time. In this case, cows in $1 \times 8$ showed the highest herbage disappearance. This supports previous comments regarding the longer lasting effect of deprivation compared with a net number of hours of available grazing time on the animal's motivation to eat at the time to face the GS. Moreover, this evidence shows the short-term effect of the temporal perception mentioned before on initial herbage intake rates. At time $2(2 \mathrm{~h}$ after GS started), cows in $1 \times 8$ continued having greater (2.5 times) herbage disappearance rates than cows in $2 \times 4$. This trend further increased toward the end of the GS. At time 3.5, the herbage disappearance rate for $1 \times 8$ cows was 6.5 times greater than for cows in $2 \times$ 4. Such a dynamic may indicate a differential balance and strength of stimuli or motivation for cows to keep eating or to stop. Finally, CTL cows' smooth reduction of herbage disappearance rate could be explained by a gradual increase in satiety signals as the GS progressed, as suggested by Gregorini et al. (2007a) and Gregorini et al., (2009).

\section{Ghrelin and NEFA Concentrations Before the First GS}

The treatments applied in the present study led cows to face the GS with different hunger levels, which is 
consistent with the differences in ghrelin and NEFA concentrations before the GS (Table 4) and the differences in herbage intake and foraging behavior during the GS. Ghrelin is a powerful orexigenic agent (Wren et al., 2000; Roche et al., 2008a), whereas NEFA is an index of the "readiness" to consume more food (Van Itallie and Hashim, 1960), an indirect indicator of energy status (Fox et al., 1991) and feeding frequency (Scrimgeour et al., 2008). For example, Scrimgeour et al. (2008) reported increased concentrations of NEFA when feeding pigs twice a day and further elevated concentrations when feeding them once a day compared with an ad libitum feeding regimen. Kolver and MacMillan (1993) reported that, under conditions of unrestricted access to pasture, grazing dairy cows might not have diurnal fluctuations in blood NEFA. These data highlight further the treatment effect found in this study. Nakazato et al. (2001) and Sugino et al. (2004) hypothesized about the possibility that the orexigenic property of ghrelin may be involved in determining feeding behavior mechanisms. The observable changes in foraging behavior during the GS in response to treatment are consistent with this hypothesis, which is supported further by the results of Gregorini et al. (2009). Within the context of the GS, the present results add more detail to these potential relationships.

\section{CONCLUSIONS}

Moderate restriction of available grazing time per se may have no effect on daily herbage intake if the amount of herbage allocated does not constrain cattle to accomplish compensatory foraging strategies. However, at the same restriction level, the timing of such a restriction may lead to differential food deprivation. This establishes a different internal state (set of positive and negative internal stimuli to eat) at the time of the first and most important grazing session, which changes their reaction (tactics of a determined/planned foraging strategy) to the perception of the same feed resource. Strategic management of such a reaction may help dairy farmers to better allocate time on pasture.

\section{ACKNOWLEDGMENTS}

We thank the DairyNZ technicians group for their invaluable help before and during the data collection period and analysis. The authors also acknowledge David Clark, Kevin A. Macdonald, Brian de la Rue, Rob Wientjes, Julio Burges, and the staff of DairyNZ's Scott farm for their help during the grazing behavior measurements, as well as John Roche for his critical review, ideas, and comments on the manuscript.

\section{REFERENCES}

Abrahamse, P. A., J. Dijkstra, B. Vlaeminck, and S. Tamminga. 2008. Frequent allocation of rotationally grazed dairy cows changes grazing behavior and improves productivity. J. Dairy Sci. 91:2033-2045.

Allden, W. G., and I. A. Whittaker. 1970. The determinants of herbage intake by grazing sheep: The interrelationship of factors influencing herbage intake and availability. Aust. J. Agric. Res. 21:755-766.

Chilibroste, P., D. A. Mattiauda, F. Elizondo, and A. Coster. 2004a. Herbage allowance and grazing session allocation in dairy cows. Effect on milk production and composition. Paper 25 in Proc. II Int. Symp. Grassland Ecophysiology and Grazing Ecology, Curitiba, Brazil. A. Moraes, E. Pizarro, P. C. Carvalho, S. Carneiro da Silva, and J. R. Dittrich, ed. Universidade Federal do Parana, Curitiba, Brazil.

Chilibroste, P., P. Soca, D. A. Mattiauda, and O. Bentancur. 2004b. Incorporation of short term fasting in grazing and feeding management strategies for cattle: An integrated approach. Proc. II Int. Symp. Grassland Ecophysiology and Grazing Ecol. Curitiba, Brazil. J. Pizarro, ed. Universidade Federal do Parana, Curitiba, Brazil.

Chilibroste, P., P. Soca, D. A. Mattiauda, O. Bentancur, and P. H. Robinson. 2007. Short-term fasting as a tool to design effective grazing strategies for lactating dairy cattle: A review. Aust. J. Exp. Agric. 47:1-10

Chilibroste, P., S. Tamminga, and H. Boer. 1997. Effects of length of grazing session, rumen fill and starvation time before grazing on dry matter intake, ingestive behavior and dry matter rumen pool sizes of grazing lactating dairy cows. Grass Forage Sci. 52:249 257.

Day, J. E., I. Kyriazakis, and P. Rogers. 1998. Food choice and intake: A unifying framework of learning and feeding motivation. Nutr. Res. Rev. 11:25-43.

Day, J. E. I. K., and P. Rogers. 1997. Feeding motivation in animals and man: A comparative review of its measurements and uses. Nutr. Abstr. Rev. A 68:107-117.

Dougherty, C. T., N. W. Bradley, P. L. Cornelius, and L. M. Lauriault. 1989. Short-term fasts and the ingestive behaviour of grazing cattle. Grass Forage Sci. 44:295-302.

Forbes, J. M. 1995. Voluntary Food Intake and Diet Selection in Farm Animals. 1st ed. CAB International, Wallingford, UK.

Fox, M. T., D. Gerrelli, S. R. Pitt, and D. E. Jacobs. 1991. The relationship between appetite and plasma non esterified fatty acid in housed calves. Vet. Res. Commun. 15:127-133.

Galli, J. R., and C. A. Cangiano. 1999. Análisis de posibles escenarios en el uso del ConPast 3.0. ConPast 3.0. Programa de computación para la estimación del consume de bovinos en pastoreo. C. A. Cangiano, ed. INTA-EEA Balcarce, Buenos Aires, Argentina.

Gibb, M. J. 1998. Animal grazing/intake terminology and definitions. Pages 21-37 in: Pasture Ecology and Animal Intake. Proc. Workshop Concerned Action. AIR3-CT93-0947h. Occasional Publ. No. 3. Teagasc, Dublin, Ireland.

Gregorini, P., M. Eirin, M. H. Wade, R. Refi, M. Ursino, O. Ansin, and S. A. Gunter. 2007b. The effects of a morning fasting on the evening grazing behavior and performance of strip-grazed beef heifers. Prof. Anim. Sci. 23:642-648.

Gregorini, P., S. A. Gunter, and P. A. Beck. 2008. Matching plant and animal processes to alter nutrient supply in strip grazed cattle: Timing of herbage and fasting allocation. J. Anim. Sci. 86:10061020.

Gregorini, P., S. A. Gunter, C. A. Masino, and P. Beck. 2007a. Effect of ruminal fill on short-term intake rate and grazing dynamics. Grass Forage Sci. 62:346-354.

Gregorini, P., K. J. Soder, and R. S. Kensinger. 2009. The effects of rumen fill on short-term ingestive behavior and circulating concentrations of ghrelin, insulin and glucose of dairy cows foraging vegetative micro-swards. J. Dairy Sci. 92:2095-2105.

Hirata, M., T. Iwamoto, W. Otozu, and D. Kiyota. 2002. The effects of recording interval on the estimation of grazing behavior of 
cattle in a daytime grazing system. Asian-australas. J. Anim. Sci. 15:745-750.

Hodgson, J. 1985. The control of herbage intake in the grazing ruminant. Proc. Nutr. Soc. 44:339-346.

Houston, A. I. 1993. The importance of state. Pages 10-31 in Diet Selection: An Interdisciplinary Approach to Foraging Behaviour. R. N. Hughes, ed. Blackwell, Oxford, UK.

Iason, G. R., A. R. Mantecon, D. A. Sim, J. Gonzalez, E. Foreman, F. F. Bermudez, and D. A. Elston. 1999. Can grazing sheep compensate for a daily foraging time constraints? J. Anim. Ecol. 68:87-93.

Illius, A. W., and N. S. Jessop. 1996. Metabolic constraints on voluntary intake in ruminants. J. Anim. Sci. 74:3052-3062.

Ivlev, V. S. 1961. Experimental ecology of the feeding of fishes. Yale. Univ. Press, New Haven, CT.

Jensen, P., and F. M. Toates. 1993. Who needs 'behavioural needs'? Motivational aspects of the needs of animals. Appl. Anim. Behav. Sci. 37:161-181.

Kennedy, E., M. O'Donovan, M. McEvoy, and J. P. Murphy. 2009. Effect of restricted access time to pasture on dairy cow milk production, grazing behavior and dry matter intake. J. Dairy Sci. 92:168-176.

Kolver, E. C., and K. L. MacMillan. 1993. Short term changes in selected metabolites in pasture fed dairy cows during peak lactation. Proc. N.Z. Soc. Anim. Prod. 53:77-81.

Kristensen, T., F. Oudshoorn, L. Munksgaard, and K. Soegaard. 2007. Effect of time at pasture combined with restricted indoor feeding on production and behaviour in dairy cows. Animal 1:439-448.

Laca, E. A., L. A. Shipley, and E. D. Reid. 2001. Structural antiquality characteristics of range and pasture plants. J. Range Manage. 54:413-419.

Macoon, B. L., E. Sollenberger, J. E. Moore, C. R. Staples, J. H Fike, and M. Portier. 2003. Comparison of three techniques for estimating the forage intake of lactating dairy cows on pasture. J. Anim. Sci. 81:2357-2366.

Mattiauda, D. A., S. Tamminga, F. Elizondo, M. J. Gibb, and P. Chilibroste. 2004. Effect of allowance and timing of grazing sessions on dairy cows grazing permanent pastures. in Proc. II Int. Symp. Grassland Ecophysiology and Grazing Ecology, Curitiba, Brazil. A. Moraes, E. Pizarro, P. C. Carvalho, S. Carneiro da Silva, and J. R. Dittrich, ed. Universidade Federal do Parana, Curitiba, Brazil.

McEvoy, M., M. O'Donovan, J. P. Murphy, F. O'Mara, T. Boland, and L. Delaby. 2007. Comparison of two techniques to estimate herbage intake in grazing dairy cows. Agric. Res. Forum, Tullamore, Co. Offaly, Ireland.

Nakazato, M., N. Murakami, Y. Date, M. Kojuma, H. Matsue, K. Kangawa, and S. Matsukura. 2001. A role for ghrelin in the control of feeding. Nature 409:194-198.

Newman, J. A., P. D. Penning, A. J. Parsons, A. J. Harvey, and R. J. Orr. 1994. Fasting affects grazing behaviour and diet preference of grazing sheep. Anim. Behav. 47:185-193.

Ørskov, E. R., and I. McDonald. 1970. The estimation of protein degradability in the rumen from incubation measurement weighed according to the rate of passage. J. Agric. Sci. Camb. 92:499508.

Patterson, D. M., D. A. McGilloway, A. Cushnahan, C. S. Mayne, and A. S. Laidaw. 1998. Effect of duration of fasting period on short term intake rates of lactating dairy cows. Anim. Sci. 66:299305.

Payne, R. W., S. A. Harding, D. A. Murray, D. M. Soutar, D. B. Baird, A. I. Glaser, I. C. Channing, S. J. Welham, A. R. Gilmour, R.
Thompson, and R. Webster. 2008. GenStat Release 11 Reference Manual, Part 2 Directives. VSN International, Hemel Hempstead, UK.

Perez-Ramirez, E., R. Delagarde, and J. L. Payreaud. 2009. Restricting daily time at pasture at low and high herbage allowance: Effects on herbage intake and behavioral adaptation of lactating dairy cows. J. Dairy Sci. 92:3331-3340.

Pittroff, W., and P. Soca. 2006. Physiology and models of feeding behavior and intake regulation in ruminants. Pages 278-301 in Feeding in Domestic Vertebrates: From Structure to Behaviour. V. Bels, ed. CAB International, Wallingford, UK.

Poppi, D. P., T. P. Hughes, and P. J. L'Hullier. 1987. Intake of pasture by grazing ruminants. Pages 55-64 in Livestock Feeding on Pasture. A. M. Nicol, ed. New Zealand Society of Animal Production Occasional Publication no. 10, Christchurch, New Zealand.

Roche, J. R., D. Blache, D. Miller, J. K. Kay, A. J. Sheahan, and D. Miller. 2008a. Neuroendocrine and physiological regulation of intake in domesticated ruminants: A review. Nutr. Res. Rev. 21:207-234.

Roche, J. R., A. J. Sheahan, L. M. Chagas, and R. C. Boston. 2008b. Short communication: Change in plasma ghrelin in dairy cows following an intravenous glucose challenge. J. Dairy Sci. 91:10051010.

Rook, A. J., C. A. Huckle, and P. D. Penning. 1994. Effects of sward height and concentrate supplementation on the ingestive behaviour of spring calving dairy cows grazing grass clover swards. Appl. Anim. Behav. Sci. 40:101-112.

Scrimgeour, K., M. J. Gresham, L. R. Giles, P. C. Thomson, P. C. Wynn, and R. E. Newman. 2008. Ghrelin secretion is more closely aligned to energy balance that with feeding behaviour in the grower pig. J. Endocrinol. 198:135-145.

Soca, P. 2006. Estrategia de rumiantes a pastoreo como respuesta a la intervención en el patrón diario de conducta. In Sustentabilidade em Sistemas Pecuarios: Int. Workshop. B. Ferriani, ed. Universidad estadual de Maringá, Paraná, Brazil.

Soca, P., V. Beretta, M. Heinzen, and O. Bentancur. 2002b. Effect of pasture height and control of grazing time on grazing behavior and defoliation dynamic of growing beef cattle. In: Symposium responding to the increasing global demand for animal products. Br. Soc. Anim. Sci., Universidad Autónoma de Yucatán, México. BSAS, Merida, Mexico.

Soca, P., H. Gonzáles, and H. Manterola. 2002a. Foraging strategy of dairy cows. Literature review. Rev. Cs. Anim. 25:119-125.

Staddon, J. E. R. 2003. Adaptative Behavior and Learning. 2nd (internet) ed. Cambridge University Press, New York, NY. http:// psychweb.psych.duke.edu/department/jers/abl/TableC.htm

Sugino, T., Y. Hasegawa, Y. Kurose, M. Kojima, K. Kangawa, and Y. Terashima. 2004. Effects of ghrelin on food intake and neuroendocrine function in sheep. Anim. Reprod. Sci. 83:183194.

Van Itallie, T. B., and S. A. Hashim. 1960. Biochemical concomitants of hunger and satiety in man. Am. J. Clin. Nutr. 8:587-593.

Wertz-Lutz, A. E., T. J. Knight, R. H. Pritchard, J. A. Daniel, J. A. Clapper, A. J. Smart, A. Trenkle, and D. C. Beitz. 2006. Circulating ghrelin concentrations fluctuate relative to nutritional status and influence feeding behavior in cattle. J. Anim. Sci. 84:3285-3300.

Wren, A. M., L. J. Seal, M. A. Cohen, A. E. Brynes, G. S. Frost, K. G. Murphy, W. S. Dhillo, M. A. Ghatei, and S. R. Bloom. 2000. Ghrelin enhances appetite and increases food intake in humans. J. Clin. Endocrinol. Metab. 86:5992-5995. 